\title{
Breaking the Mold with Humor: Images of Women in the Visual Media \\ Sheri Klein
}

Comics as visual media humor have shaped, reinforced and revisioned generations of attitudes and beliefs about ourselves and others. While the majority of comics have perpetuated stereotypical and limited views of women, comics in recent years have challenged these images.

To explain how images of women have been challenged in comics I will address: (1) the construction of femininity and sexuality in comics and their roots in 'fine art' images, (2) fragmented images of women in mainstream comics, (3) images of working women in mainstream comics, (4) alternative images of women in feminist and underground comix and (5) the importance of including visual media humor in a visual arts curriculum.

\section{Femininity in Western Art}

In order to understand the portrayal of women in the visual media, we can turn to images in western art. Visual images throughout art history have revealed the status of women judged by their appearances, their femininity created by dress and bodily attributes. The 'ideal' woman, clothed and nude, appears in art beginning in the Renaissance through the present day. An example of the ideal woman is seen in the painting La Grande Odalisque by Ingres (1780-1867). The woman in the painting is arranged to display herself to a male voyeur, the surveyor, as she looks away out of the picture (Berger, 1977).

Both comics and painting traditions have produced particular ways of seeing the feminine body with the male viewer in mind (Betterton, 1987). The spectator is always assumed to be male and the ideal woman is always assumed to be there to flatter him. As women are depicted surveying themselves and their femininity, they do to themselves what men do to them. The woman turns herself into an object and she comes to consider the surveyor and the surveyed as part of her identity (Berger, 1977).

Feminist analysts of film agree that women are presented as objects of the male gaze (Aronowitz, 1989). The male gaze represents longing and desire; in contrast to the female gaze which is coy, empty, and non-confrontational. This can be seen in the comics "Anne Howe" (ca. 1930) and "Dumb Dora" (ca. 1920) where the female characters are objectified as desire, but not desiring themselves. 


\section{Fragmented Images of Women in Visual Media}

Pollack, Winship, and Conrad argue that we cannot separate the representation and objectification of women in visual images from social construction of gender and sexuality (Betterton, 1987). Mainstream comics involve the marketing of erotic appeal of women's bodies at the expense of fostering unfavorable stereotypes. These social constructions and narrow definitions are reinforced in comics where women are arranged and posed like mannequins. They often hold "props" which refer to domestic or feminine activity as in the comic "Tiffany Jones"(ca. 1964). Smiling coyly, "Tiffany" holds a mixing bowl while entrenched in thoughts of domestic life.

If you open any popular woman's magazine, you can find women: (1) caressing objects, (2) standing behind men or animals, (3) turning their heads to the side or down to suggest appeasement, (4) grinning widely, (5) posed in a bashful knee pose, (6) gazing at their hands, (7) talking on the telephone and smiling, and (8) snuggling with children, animals, and men (Goffman, 1976). Women in comics and advertisements are visually and symbolically fragmented. Signified by their hands, lips, feet, legs, eyes, mouth, nose, ears, and hair, their identities revolve around the manipulation of their body parts as if they were mere instruments (Le Moncheck, 1985).

In the comic "Dilly" (1958-1962), the main character, who is a woman, is objectified and fragmented into glamorized body parts. In one comic "More fuller, luscious lips" refers to her sexuality and ultimately her desirability. The sexuality of women in advertisements and in comics is dependent upon the presence of a man or the ability to get a man. Women are seen through the eyes of a real or potential man. These images of women tell us what femininity and sexuality are supposed to be in the time and place that they were created (Connell, Davis, Mcintosh \& Root, 1989).

The sexuality of women in mainstream comics is defined by accentuated legs, eyes, mouth, and breasts to connote beauty and allure the viewer. Long, flowing, wavy hair, signifying passion and sexual power (Berger, 1977), occurs in many mainstream comics. The women in "Petting Patty" (ca. 1920), "Minnie Ha Cha" (ca 1930), "Betty Boop" (ca. 1930), and "Babe, Darling of the Hills" (ca. 1949) are depicted as flirtatious and suggestive, with great attention paid to their body parts.

These strips are a few examples of mainstream comics which contribute to the construction of superficial images of women in the media. The roles of women in mainstream comics have included the seductress, as in the above examples, the plotting girlfriend ("Olive Oyl" ca. 1930 and "Betty and Veronica" ca. 1960) or the scheming wife ("Blondie" ca. 1930, "Kitty McCoy" ca. 1920). Once married, women in the comics lose their sexual prowess and often evolve into scheming and clever wives.

\section{Working Papers in Art Education 1991}




\section{Working Women in Mainstream Comics}

Historically, women's work in mainstream comics has primarily centered around romance and domestic life. Women were seen in stereotypical work and supporting roles to men. Yet, as social and political changes have occurred in our society, these changes are echoed in contemporary comics in which new roles for women are depicted.

Women were first seen working in the comics around 1905; suffragettes were marching for the right to vote. (Franzen \& Ethiel, 1988). These comics, which were drawn by men, depicted these women with ridicule, contempt, fear, and little sympathy.

"Somebody's Stenog" (ca. 1917-40) is the first example of an image of an independent working woman in the comics, an office worker, who was neither tied to husband or parent (Horn, 1977). In the 1920s, "office girl" strips, such as "Tillie the Toiler" and "Winnie Winkle", continued to be presented. Women were seen in traditional and non-professional roles which glamorized working and focused on romances of the female characters.

Coinciding with these images of working women in the comics were images of women in the military. It was not until World War II, however, that women were depicted on the newspaper page and in comic books as going to war. In the 1930s and 1940s, women were seen in adventurous and daring roles, such as "Brenda Starr", reporter, "Connie", private eye and explorer, "Debbie Dean", journalist and "Jenny Dare", navigator. Probably, the most important strip of the 1940s was "Wonder Woman" that mirrored a bold image of women in the comics. Representative of early feminist comics, her adventures revolved around the rescue of other women and her message was self-reliance and personal strength.

Post-World War II images of women in the visual media reflected a conservative social and political climate. Women's place in the home was reinforced in the media by idyllic images of family life and happy homemakers. Love and romance comics reinforced women making choices and sacrifices for love, always with a happy ending. (Benton, 1989).

Despite the image of security and contentment presented at this time in comics, images began to surface expressing discontent. Rhoda Kellogg's cartoons (ca. 1954), expressed anger and frustration about expectations for women. In her autobiographical text combined with doodle-like caricatures, she expressed a wide range of emotions. In one of her comics, she says, "I will feel better in something light and fluffy." This emphasis on appearance reveals that the real source of self-esteem still for many women laid in the way they looked (Le Moncheck, 1985).

The women's movement took on the politics of the visual image in mass media and feminists challenged the shallow depiction of women. As a

\section{Working Papers in Art Education 1991}


result, comics began to reveal a new and diversified image of women and their experiences.

What resulted were comics depicting independent women striking out on their own. The "Girls of Apt. 3G", "Joannie Caucus" and "Friday Foster" (ca. 1960) are examples of career girls living an active lifestyle, having unconventional attitudes, seen in professional careers (teaching, law, and fashion photography) and not dependent on men.

\section{Feminist Comic Humor}

Humor expressed through the comic character did not occur until after the women's movement had begun. Women were not supposed to have a sense of humor as it was associated with (male) intellect (Walker, 1990). Women's humor in mainstream comics centered around domestic life and women were often the target for humor. Feminist comic humor recognizes that the personal is political by confronting sexism, gender and economic issues. Women in feminist comics have a consciousness and an awareness about the inequities and problems they face as women.

The cartoons of the 1970s shared the same women's struggles and conflicts with early twentieth century cartoons. Humor in the feminist comics of the 1980 s continued to raise consciousness and protest existing conditions of oppression (Walker, 1990). Feminist cartoonist, Balbul, who confronts social, political, and economic issues in her work says:

Cartooning is dominated by white, male consciousness and its white, male definitions of humor. Feminist humor involves reflecting the struggle. (Walker, 1990, p. 51)

In her work, Balbul expresses social inequities and sexism with a biting sense of humor. We can see the difference in consciousness when we look back to the comic "Miss Peach" (ca. 1950) who always managed to keep her sunny disposition even in the face of outrageous provocation (Horn, 1977).

Another feminist comic artist, Nicole Hollander, now seen in daily newspapers, exposes the inequities facing women while challenging assumptions about male and female relationships. Humor as a vehicle for expressing frustration about overwhelming social problems is also seen in "Mafalda". A comic written by an Argentinean man named Quino, it portrays a young feminist who is misunderstood as she confronts social injustice (Foster, 1980).

Feminist comics also challenge stereotypical definitions of femininity and feminine behaviors with humor. Lynda Barry, in her "I Love My Body" comic, parodies the conventions that women buy into, to construct and reconstruct themselves. Implants, dental bonding, cosmetic surgery, are a 
few ways she describes for a woman to become an object of desire. At the extreme, contemporary French cartoonist, Claire Bretecher, depicts women as androgynous (Sherzer, 1980).

Similarly, contemporary artist, Cindy Sherman, questions the meaning of glamour and beauty. In her photographs, she moves in and out of feminine as well as androgynous roles (Pelfrey, 1985). Another photographer, Robert Mappelthorpe, in his photograph of "Lisa Lyons" a professional body builder, demonstrates the potential for women to be viewed as strong and glamorous. These current images, which integrate masculinity and femininity, offer the possibility for redefining traditional gender roles (Betterton, 1987) and provide a source for new images of women in the comics.

\section{Humor in Underground Comix}

"Mafalda", like the other feminist comic characters, presents her raised consciousness in an approachable manner. In contrast, underground comix (not comics) present the realities of women in a rather straightforward manner with greater realism. Confronting socially conditioned expectations, these comix depict fat women, women in conflict between real and idealized love, and women with economic and marital problems.

Much of the humor in these comix is based upon appearances, clothing, cosmetic and hair styles, and household furnishings which delineate a wide variety of life styles, from working women to middle class parents to commune tenants. Women underground comix artists draw strength from their experiences, and most women have been indoctrinated since childhood with the need to be sensitive to nuances of appearances (Mitchell, 1981).

Women in these comix struggle to survive and succeed, without depending on men for fulfillment. The comix "A Visit with the Artist" (ca. 1980) by Trina Robbins presents a harsh reality of a struggling artist with a child. Trina is depicted glamorously attired by her drawing board as the voice of her child interrupts her fantasy of romance, leisure, and high style (Mitchell, 1981). As the women in mainstream comics often wait to be rescued by a man, or act as a subordinate helper to dominant, active males, women in the underground comix realize they are their greatest resource.

Dianne Noomin's comix explore the grotesqueness of glamour, the social expectations placed upon women to be glamorous, and how women construct themselves to be objects for the male gaze. Her glamorous bank robbing character, Didi Glitz, exploits society's tendency to judge respectability by costume. Artist Lee Marr confronts society's expectation for women to be thin in her comix "Pudge, Girl Blimp". In an adventure about an overweight girl, Marr delves into issues of societal rejection, standards of perfection, and self-acceptance with a complex plot and numerous subplots (Mitchell, 1981).

Working Papers in Art Education 1991 
Yet, in visual mass media images today, females more often than men, are still presented in passive roles (Branbant \& Mooney, 1986). Young girl readers of comics, due to the nature of most story lines in mainstream comics, are not engaged with a heroine who is making moral and/or intellectual decisions. Influence of these comics is far reaching and entraps young readers with ideology that is sugar-coated and with content that is escapist rather than conscious raising (Barker, 1989).

\section{Comics in a Visual Arts Curriculum}

In a fine arts curriculum, the study and production of visual media humor is important for several reasons. First, comics are of high interest to both female and male students; they enjoy reading, making, and collecting comic books. This interest can be carried into the art classroom to provide opportunities for comic book production, aesthetic, art history and art criticism experiences. The comic book can be a format for integrating drawing, painting, writing, design and humor with personal, social, and political issues, resulting in dynamic visual narratives. There are now even comic book designing programs for the Maclntosh and Amiga computers on the market which can unite students' interests in comic art with computer art.

Second, there are strong connections between images of women in 'fine art' and in the comics. Students can understand the enormous influence of graphic arts, including comic art, on modern art. A recent exhibition from the Museum of Modern Art, "High \& Low: Modern Art and Popular Culture", links comic art traditions and styles with twentieth-century painting such as Pop Art (Weiss, 1991).

The idea of comics as art is gaining wider acceptance as more exhibitions like this are devoted to showing the work of contemporary comic artists. "Misfit Lit: Contemporary Comic Art" is another example of a recent exhibition (at the Center on Contemporary Art, Seattle, WA) which celebrates the diversity of contemporary comic art work by both established and lesser known artists.

Comics in a visual arts curriculum can also teach students how to read mass media images for obvious, intended, and subliminal messages. Images in magazines with male readership can be contrasted with magazines for purely female readership. Props, text, elements and principles of design, fashion, and gestures can be analyzed as well as social, political, and gender issues.

Students can be sensitized to inequities through the study of comics. They can realize that women of color are rarely seen in comics today and that men are represented more than women (Chavez, 1985). The stereotyping of ethnic groups in the visual media can be discussed and students can learn a great deal about the global portrayal of women through cross-cultural comparisons of images of women in the comics.

Working Papers in Art Education 1991 
The study of images of women in the comics can present opportunities to discuss and analyze humor. Humor as I have shown can be used both to subordinate and liberate. Humor in mainstream comics often has demoralized and dehumanized women, poking fun at their appearances and ineptness. Feminist humor is never a joke as it disrupts the male comic traditions based on the humiliation of women (Betterton, 1987).

The power of humor should be to help us see in a new way and it can expose us to what it means to be human, enlarging our view of ourselves and others. For example, the humor of comic artist Andrea Natalie, in her strip "Stonewall Riots", helps us to expand a notion of what constitutes a family, as Ida Marx's "Apples and Oranges" examines class and economic barriers.

Studies of mainstream, feminist, and underground cartoonists can be particularly inspirational to young female students. Girls can learn that women cartoonists work in editorial, magazine, newspaper cartooning, and animation (Horn, 1977) as well as in many areas of media production. Female cartoonists today who are gaining exposure and recognition are helping to reconstruct more positive ways to represent women's realities. As most female cartoonists remain unrecognized, the study of visual media can help students rediscover these artists of merit.

\section{Conclusion}

More comic books have been printed, read, and sold than all of the Top-Ten best-selling books of the last fifty years (Benton, 1989). Comics have and will continue to reach generations of readers, shaping their consciousness and raising it (Walker, 1990). I believe that comics will continue to play an important role in our culture because of their mass appeal and world-wide circulation. At their best, comics hold up a mirror to our society.

Differences in class, race and age produce different understandings of visual images. Humor in visual media images can communicate messages across cultures barriers, and time. As a tool, humor has the power to break the mold, change perceptions about ourselves and others, and reduce the fragmented image of women in the visual media.

\section{References}

Aronowitz, S. (1989). Working-class identity and celluloid fantasies in the electronic age. In P. Friere \& R. Simon (Eds.), Popular culture, schooling, and everyday life (pp. 197-217). NY: Bergin \& Garvey.

Barker, M. (1989). Comics, ideology, power, and the critics. Manchester: Manchester University Press.

Working Papers in Art Education 1991 
Benton, M. (1989). The comic book in America: An illustrated history. Dallas, TX: Taylor.

Berger, J. (1977). Ways of seeing. London: Penguin Press.

Betterton, R. (1987). Looking on: Images of femininity in the visual arts and media. London: Pandora Press.

Branbant, S., \& Mooney, L. (1986). Sex role stereotyping in the Sunday comics: Ten years later. Sex Roles, 14 (3-4), 141-148.

Chavez, D. (1985). Perpetuation of gender inequality: Content analysis of comic strips. Sex Roles, 13 (1-2), 93-101.

Connell, M., Davis, T., Mclntosh, S., \& Root, M. (1989). Romance and sexuality: Between the devil and the deep blue sea? In A. McRobbie \& T. McCabe (Eds.), Feminism for girls: An adventure story (pp. 159-160). London: Routledge \& Kegan Paul.

Foster, D. (1980). Mafalda: An Argentina comic strip. Journal of Popular Culture, 14 (3), 497-508.

Franzen, M., \& Ethiel, N. (1988). Make way: 200 years of women in the cartoons. Chicago: Chicago Review Press.

Goffman, E. (1976). Gender advertisements. Washington, DC: Society for Anthropology of Visual Communication.

Horn, M. (1977) Women in the comics. New York: Chelsea House.

Kellogg, R. (1954). Portraits of a lady. San Francisco, CA: Johnson.

Le Moncheck, L. (1985). Dehumanizing women: Treating persons as sex objects. Totowa, NJ: Rowman \& Allanheld.

Misfit Lit: Contemporary comic art. Seattle, WA: Fantagraphics Books.

Mitchell, D. (1981). Women libeled: Women's cartoons of women. Journal of Popular Culture, 14 (4), 597-609.

Pelfrey, M. \& R. (1985). Art and mass media. New York: Harper \& Row.

Sherzer, D. (1980). Claire Bretecher: Queen of the BD. Journal of Popular Culture, 14 (3), 394-404.

Walker, N. (1990). Humor as Protest. Women of power, 14, 76-90.

Weirdo Magazine (1986) v. 18. San Francisco, CA: Last gasp eco funnies. 
Weiss, H. (1991, February 17). High \& low: Exhibit links art and popular culture. The Chicago Sun-Times, Arts \& Show, pp. 1, 5. 